\title{
The effect of constant darkness and short light periods on the survival and physiological fitness of two phytoplankton species and their growth potential after re-illumination
}

\author{
Bettina Walter $\cdot$ Janna Peters $\cdot$ Justus E. E. van Beusekom
}

Received: 25 October 2016/Accepted: 7 September 2017/Published online: 20 September 2017

(C) The Author(s) 2017. This article is an open access publication

\begin{abstract}
We tested the survival potential and fitness of two different algae strains (the diatom Thalassiosira weissflogii and the cryptophyceae Rhodomonas sp.) under different growth conditions (complete darkness and short light intervals, simulating conditions in a deep mixed water column) at different temperatures, plus the effect of these conditions on the physiological fitness and growth after re-illumination was examined. Both species survived the experimental conditions without significant cell loss or physiological damage. Two different survival strategies were observed: (1) the diatom $T$. weissflogii immediately reduced its metabolic rate and stopped cell division. The effect on chlorophyll $a$ (chl- $a$ ) content and photosynthetic
\end{abstract}

Handling Editor: Miquel Lurling.

B. Walter $(\bowtie) \cdot$ J. Peters

Institute for Hydrobiology and Fisheries Science, Center for Earth System Research and Sustainability (CEN), Klima Campus, University of Hamburg, Grosse Elbstrasse 133, 22767 Hamburg, Germany

e-mail: bettina.walter@swansea.ac.uk

Present Address:

B. Walter

College of Science, Swansea University, 138 Wallace

Building, Singleton Park, Swansea SA28PP, UK

Centre of Material and Coastal Research,

Helmholtz-Zentrum Geesthacht, Max-Planck-Strasse 1,

Geesthacht, Germany

\section{J. E. E. van Beusekom}

capacity was negligible. At $10{ }^{\circ} \mathrm{C}, T$. weissflogii used the short light windows to metabolize carbohydrates and growth. (2) The cryptophyte Rhodomonas sp. initially continued to grow after transfer into all trials. However, the cell number decreased after day 6 . Carbohydrate and chl- $a$ content went on to decrease dramatically (70 and 50\%, respectively). After 3 days of re-illumination, T. weissflogii grew faster than of Rhodomonas sp.. The diatom seemed to benefit from better start conditions and would out-compete the cryptophyte during a spring bloom. Our results highlight that these algae groups have different strategies in dealing with darkness, which potentially endow diatoms with a competitive advantage in deep mixed waters and in the season of early spring.

Keywords Light limitation - Dark survival · Growth · Ocean mixing · PAM fluorometry · Phytoplankton physiology $\cdot$ Re-illumination
Abbreviation
chl- $a \quad$ Chlorophyll a
$F_{\mathrm{v}} / F_{\mathrm{m}} \quad$ Maximum quantum yield
PAM Pulse amplitude modulation
rETRmax Maximal relative electron transport rate RLC Rapid light curve 


\section{Introduction}

Phytoplankton is exposed to darkness on timescales varying from daily, light-dark rhythm, to years if cells sink out of the water column and need to survive in the sediment. In the temperate ocean, light availability can be extremely low during winter convection in the North Atlantic, when phytoplankton cells can be exposed to dark periods ranging from days to weeks (McMinn and Martin 2013). Phytoplankton cells need to survive these conditions in order to seed the subsequent spring bloom (Backhaus et al. 2003). Some phytoplankton species can survive darkness in the space of days to several months (Antia 1976; Jochem 1999; Popels et al. 2007) with temperature having a negative impact on survival (Antia 1976; Dehning and Tilzer 1989). Mechanisms to survive prolonged darkness include the formation of resting cysts or cells (Durbin 1978; Smetacek 1985; McQuoid and Hobson 1996), the reduction in physiological activity (Antia 1976; Wasmund 1989; Peters 1996; Furusato et al. 2004) or mixotrophy by switching to heterotrophic feeding (e.g., White 1974; Harris 1978; Deventer and Heckman 1996). Survival strategies and adaptation potential can be species specific (Peters 1996). Jochem (1999) investigated survival of several algae in darkness and noted two different survival strategies he categorized as: type $I$ cells-which can suppress their metabolism and therefore withstand long periods of darkness, but can also react quickly to changing environmental conditions. This strategy is typified by diatoms, which dominate early spring blooms in temperate and cold regions (Barlow et al. 1993; Wassmann et al. 1999; Wiltshire et al. 2008). Second is the type II cells, which remain physiologically active during darkness but are better adapted to nutrient limitation. This type of response is typical of small flagellates, which dominate the environment after the spring bloom (Colebrook 1979; McQuattersGollop et al. 2007).

Within taxonomic groups, the various species have exhibited differently. For example, Thalassiosira puntigera lost about $65 \%$ of its cellular chlorophyll $a$ (chl-a) during 35 days of darkness, while $T$. weissflogii could survive 2 months of complete darkness without a noticeable loss of chl- $a$ (Murphy and Cowles 1997). Carbohydrates are used during dark respiration and necessary for maintaining the metabolism during long dark periods (Raven and Geider
1988). For example, Popels et al. (2007) and Dehning and Tilzer (1989) observed a decrease in carbohydrates of 70-90\% within 2 weeks in Aureococcus anophagefferens and Scenedesmus acuminatus. The schematic models of Furusato and Asaeda (2009) and Talmy et al. (2014) assume that survival in the dark depends on available carbon reserve. Largely, carbohydrates and dark survival strategies affect growth after re-illumination-however, it must be noted that experimental data supporting this hypothesis are rare.

In winter, phytoplankton species are primarily limited by the availability of light for photosynthesis. Whereas in spring, when light availability increases due to day length and stratification of the water column, phytoplankton species compete for nutrients. During this period, the species with the highest affinity for a limiting resource typically out-compete other species (Tilman 1980). Margalef (1978) suggested in his conceptual model of ecological niches that diatoms are adapted to turbulent waters with high nutrient concentrations, whereas flagellates, e.g., cryptophyceae are more adapted to nutrient-poor, stratified conditions. Under constant low-light conditions, species with a low critical light intensity are better competitors (Huisman et al. 2004). However, in deep mixed water bodies with non-homogenous distribution of light physiological flexibility provides a competitive advantage (Huisman and Weissing 1995). Hence, diatoms have a competitive advantage in the highly variable open ocean environment (Kashino et al. 2002; Wagner et al. 2006).

Information on dark survival and physiological responses of open ocean phytoplankton species is limited (Peters 1996; Murphy and Cowles 1997). Nymark et al. (2013) examined the survival of the diatom Phaeodactylum tricornutum after $48 \mathrm{~h}$ of darkness and re-illumination finding that the algae could immediately recover their photosynthetic activity. Expression of genes encoding light-harvesting complex and the photosynthetic capacity increased within $30 \mathrm{~min}$ after re-illumination. However, Nymark et al. (2013) did not report on dynamics of algae under short light pulses or in rapidly changing environments. Walter et al. (2014) observed positive growth of $T$. weissflogii at temperatures above $8{ }^{\circ} \mathrm{C}$ when exposed to $2 \mathrm{~h}$ of light per day at $120 \mu \mathrm{mol}$ photons $\mathrm{m}^{-2} \mathrm{~s}^{-1}$ (a daily light dosage of $0.864 \mathrm{~mol}$ photons $\mathrm{m}^{-2} \mathrm{~d}^{-1}$ ). However, the growth rate was lower than under a similar daily integrated light 
dosage over a period of $12 \mathrm{~h}$. Clearly, there is an obvious need for experiments elucidating the effects of variables light conditions on dark survival and subsequent re-illumination behavior.

To better understand the potential of different algae strains to survive limited light conditions or darkness, and how those conditions affect the growth potential after re-illumination, we carried out laboratory experiments exposing two different algae strains (Thalassiosira weissflogii and Rhodomonas sp.). We exposed two different functional groups for 12 days to either: constant darkness or short pulsed light conditions of 1 or $3 \mathrm{~h}$ light per day at 3 different temperatures. The aim of the study was to investigate (1) how phytoplankton physiology responded to darkness or lowlight conditions as experienced during deep mixing and (2) how these preconditions influenced the growth potential after re-illumination.

\section{Materials and methods}

Algae cultures

Thalassiosira weissflogii (Grunow) G. Fryxell \& Hasle (Bacillariophyceae; strain CCMP 1336) was obtained from the Provasoli-Guillard National Centre for the Culture of Marine Phytoplankton, and Rhodomonas sp. (Karsten) (Cryptophyceae; strain CCAC 0083) was obtained from Culture Collection of Algae at the University of Cologne. They were cultured as non-axenic cultures in the laboratory of the Institute of Hydrobiology and Fisheries Science in Hamburg (Germany). Algae were grown in autoclaved, GF/F filtered North Sea water (salinity 32) at a temperature of $15{ }^{\circ} \mathrm{C}$. For the diatom T. weissflogii, f/2 medium (Guillard and Ryther 1962) was used while a Walnes medium (McVej 1993) enriched with biotin (Stottrup and Jensen 1990) was used for Rhodomonas sp.. We illuminated with Biolux neon lamps (Osram) emitting $120 \mu \mathrm{mol}$ photons $\mathrm{m}^{-2} \mathrm{~s}^{-1}$ irradiance in a 12/12 h light/dark cycle. Algae stock cultures were kept in an exponential growth phase by changing $90 \%$ of the water with fresh nutrient-enriched filtered seawater. Growth rates were determined 1 day before the start of the experiment by measuring cell increase over the last $24 \mathrm{~h}$. Growth rate was not significantly different between $T$. weissflogii $\left(0.74 \mathrm{~d}^{-1} \pm 0.05\right)$ and Rhodomonas sp. $\left(0.79 \mathrm{~d}^{-1} \pm 0.11\right)$.
Experimental setup

The experiment was split into two parts-pre-conditions and re-illumination (Fig. 1). During the first part (pre-conditions), algae were exposed to either constant darkness or short light pulses, simulating conditions in a deep mixed water column for 12 days. Algae were exposed to complete darkness at 4,7 and $10{ }^{\circ} \mathrm{C}$. At 4 and $10{ }^{\circ} \mathrm{C}$, algae were additionally exposed to short light intervals of $3 \mathrm{~h}$ of light per day $\left(20 \mu \mathrm{mol} \mathrm{m} \mathrm{m}^{-2}\right.$ $\left.\mathrm{s}^{-1}\right)$ and at $10^{\circ} \mathrm{C}$ to $1 \mathrm{~h}$ per day $\left(20 \mu \mathrm{mol} \mathrm{m} \mathrm{m}^{-2} \mathrm{~s}^{-1}\right)$. After 12 days, algae were re-illuminated with $14 \mathrm{~h}$ light $\left(120 \mu \mathrm{mol} \mathrm{m}{ }^{-2} \mathrm{~s}^{-1}\right)$ at $10{ }^{\circ} \mathrm{C}$ for a period of 3 days.

For the first part of the experiment, stock cultures were diluted with autoclaved GF/F filtered North Sea water to a final concentration of 7.000 (T. weissflogii) and 10.000 cells $1^{-1}$ (Rhodomonas sp.) and filled into $620 \mathrm{ml}$ Greiner culture bottles. Nutrient concentrations were half of the stock culture concentration and sufficient to replete conditions given the low cell concentrations and expected growth rates. Every light and temperature combination was carried out in triplicate. After an adaptation period of 3 days, cell number and PAM fluorometry were measured every third day of the experiment (day 6,9 and 12) at the end of a light phase. Samples for cell counts were fixed with Lugol to a final concentration of $1 \%$ and stored in cold and dark no more than 2 days before analyzing with a Coulter Counter (Multisizer 3). Two Coulter Counter runs were carried out in triplicate. Cell size was determined to be between 8 and $14 \mu \mathrm{m}$ diameters for T. weissflogii and 5-9 $\mu \mathrm{m}$ for Rhodomonas sp., and only cells within this size fraction were used for calculations. The growth rate was calculated by the following equation:

$\mu=\ln \left(N_{2} / N_{1}\right) /\left(t_{2}-t_{1}\right)$,

where $\mu$ is the specific growth rate $\left(\mathrm{d}^{-1}\right)$ and $N_{1}$ and $N_{2}$ are cell numbers at time $1\left(t_{1}\right)$ and time $2\left(t_{2}\right)$, respectively.

Coulter Counter runs were also used for the determination of cell size. The overall size fraction was split into $2 \mu \mathrm{m}$ steps for T. weissflogii and $1-\mu \mathrm{m}$ steps for Rhodomonas sp. and mean diameter size was calculated. Biovolume of both species was calculated according to Olenina et al. (2006). For T. weissflogii, the geometric shape of a cylinder used for 
Fig. 1 Experimental setup

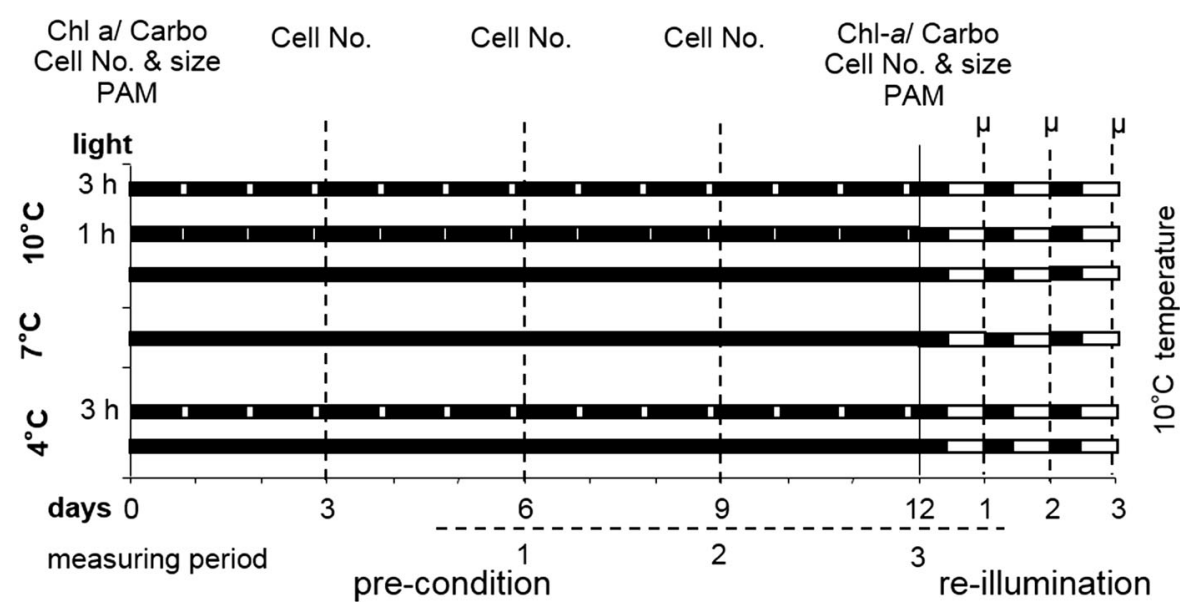

calculations. The following formula was used for volume calculations:

$V=\pi / 4 * d_{2} * h$,

The mean diameter $(d)$ was taken form the Coulter Counter calculations, and cell height $(h)$ was assumed to be $d / 1.3$ as observed for cells with a diameter of $12-15 \mu \mathrm{m}$.

The volume of Rhodomonas sp. was calculated assuming that the geometrical shape of the cell is approximated by a cone, plus a half sphere, with cell height taken from the Coulter Counter calculations and the cell diameter assumed to be half of the height:

$V=\pi / 12 * d_{2} *(h+d / 2)$,

At the last day of the pre-condition experiment (day 12), samples for cell number and volume, PAM fluorometry and biochemical analysis were taken. Sampling for biochemical analysis took place at day 0 and day 12. Duplicate samples of $50 \mathrm{ml}$ were filtered onto pre-combusted Whatman GF/C filters and frozen at $-80{ }^{\circ} \mathrm{C}$ until analysis.

$400 \mathrm{ml}$ of the algae culture from the pre-condition experiment were used for the spring bloom simulating experiment. Algae were transferred into a 11 glass beaker and filled up to a final volume of 11 with autoclaved GF/F filter North Sea water containing the same concentration of nutrients as at the start of the incubation experiment. The beakers were closed with a glass lid, and bubbled with filtered air, for a homogeneous cell distribution within the beaker. They were then randomly distributed in a temperaturecontrolled table at $10{ }^{\circ} \mathrm{C}$. Growth rate was determined every day for 3 days.
Biochemical analyses

Carbohydrates were measured after Dubois et al. (1956) and Herbert et al. (1971): Furan derivates were formed by adding $96 \%$ sulfuric acid to the sample and pentoses were converted to a-furfurylaldehyde while hexoses were transformed to 5-(hydroxymethyl)-furfurol. These aldehydes react with phenol to produce characteristically colored products. Carbohydrates were expressed as glucose equivalents. A D (+) glucose monohydrate solution was used as a primary standard, and samples were measured photometrically at $490 \mathrm{~nm}$.

Chl- $a$ was extracted in $90 \%$ acetone and analyzed photometrically at $664 \mathrm{~nm}$ and calculated after Jeffrey and Humphrey (1975).

\section{PAM fluorometry}

Chlorophyll $a$ fluorescence was measured using a Water PAM (Walz Germany). Samples were taken at the end of the light pulses for the trial simulating deep convection and at a comparable time of day for the samples incubated in complete darkness. Maximum quantum yield $\left(F_{\mathrm{v}} / F_{\mathrm{m}}\right)$ was determined after 5 min of dark adaptation, and subsequently a rapid light curve (RLC) was measured while stirring the sample for $20 \mathrm{~s}$ during the $30 \mathrm{~s}$ light incubation (Cosgrove and Borrowitzka 2006). Each treatment involved 9 consecutive, $30 \mathrm{~s}$ intervals of actinic light pulses of increasing intensity with an accompanying yield measurement at the end of each actinic interval. Blue LEDs provided the actinic light at levels of 0, 99, 143, 
$219,324,460,641,1063$ and $1529 \mu$ mol photons $\mathrm{m}^{-2}$ $\mathrm{s}^{-1}$. A maximum relative electron transport rate $\left(\mathrm{rETR}_{\max }\right)$ was calculated from these RLC. For more details on PAM methodology see Walter et al. (2014).

Data analysis and statistics

Carbohydrate and chl- $a$ contents were determined as ng cell volume ${ }^{-1}$ and calculated as percent difference of the initial value. PAM data are relative values and were also related to the initial values. Difference between measurements on T. weissflogii and Rhodomonas sp. as well as the difference between the treatments were tested by Mann-Whitney $U$ test for independent samples. Significance was accepted with a $p$ value of $\leq 0.05$. Statistic analyses were carried out with SPSS 15.0 software.

\section{Results}

Survival (pre-condition: dark and light limited conditions)

Both T. weissflogii and Rhodomonas sp. withstood 12 days of constant darkness or short light pulses without large cell losses. Growth rate of $T$. weissflogii was constantly low during the entire experiment. No significant increases or decreases of growth rate were found. During the entire preconditioning period (day $3-12$ ), a trial effect was only found at $10^{\circ} \mathrm{C}$, where growth rate was significantly higher under $3 \mathrm{~h}$ light $\left(0.02 \pm 0.01 \mathrm{~d}^{-1}\right.$ day $\left.12 ; p=0.050\right)$ incubation than under 1-h light or dark incubation.

In contrast, Rhodomonas sp. continued to grow until day 6 especially at $4{ }^{\circ} \mathrm{C} 3 \mathrm{~h}\left(0.11 \pm 0.03 \mathrm{~d}^{-1}\right)$. The growth rate decreased to zero and below during the following 6 days (lowest value $-0.3 \pm 0.01 \mathrm{~d}^{-1}$ $4^{\circ}$ dark day 12) (Fig. 2). At $4{ }^{\circ} \mathrm{C}$ (dark and $3 \mathrm{~h}$ ) and $10{ }^{\circ} \mathrm{C} 3 \mathrm{~h}$, the decrease in growth rates between day 6 and day 12 was significant $(p=0.050)$.

Although the differences in growth rate during the experiment were rather small, we could see that $T$. weissflogii withstood long periods of darkness/low light, and pulsed light was found to be better than Rhodomonas sp. as growth immediately discontinued when conditions became unfavorable. Rhodomonas sp. behaved differently by keeping up its growth rates but subsequently could not sustain this for a long time.
Biochemistry

The cell volume of both species decreased during the experiment under all tested conditions (data not shown). The cell volume of $T$. weissflogii decreased about $20 \%$ of the initial value, and the cell volume of Rhodomonas sp. decreased to $20 \%$ at $4{ }^{\circ} \mathrm{C}$ and $10 \%$ at 7 and $10{ }^{\circ} \mathrm{C}$. Because of the rather large differences in cell volume, carbohydrates (Fig. 3a) and chl$a$ (Fig. 3b) were calculated as $\mathrm{ng}\left(\mu \mathrm{m}^{-3}\right.$ cell volume $)^{-1}$ and given in percent of the initial value.

Initial carbohydrate content $T$. weissflogii was $0.76 \pm 0.7 \mathrm{ng}$ cell volume ${ }^{-1}$ and decreased in dark conditions. Temperature had a negative effect on the carbohydrate content in darkness. At $4{ }^{\circ} \mathrm{C}$, content was significantly higher $\left(0.67 \pm 0.2 \mathrm{ng}\right.$ cell volume ${ }^{-1}$ corresponding to a decrease of $12.2 \pm 24.8 \%$ ) than at $10{ }^{\circ} \mathrm{C}\left(0.42 \pm 0.1 \mathrm{ng}\right.$ cell volume ${ }^{-1}$ corresponding to a decrease of $45 \pm 13.8 \%$; $p=0.050$ ). Light led to a reduced decrease, measurably even an increase in carbohydrates under both temperature treatments. At $4{ }^{\circ} \mathrm{C}$, T. weissflogii used the short light windows of $3 \mathrm{~h}$ to accumulate carbohydrates $(0.88 \pm 0.23 \mathrm{ng}$ cell volume $^{-1}$ corresponding to an increase in $16.9 \pm 31.4 \%$ ). At $10{ }^{\circ} \mathrm{C}$, an increase in light availability led to a lower carbohydrate content. At $3 \mathrm{~h}$ light, the content was comparable to the initial value. This was the only treatment where a slightly positive growth rate occurred and, possibly, part of the carbohydrates was used for cell division.

The carbohydrate content of Rhodomonas sp. strongly decreased-up to $70 \%$ of the initial value of $2.39 \pm 0.15 \mathrm{ng}$ cell volume ${ }^{-1}$ under all tested conditions. The highest loss was found at $4{ }^{\circ} \mathrm{C}$ dark $(71.68 \pm 3.37 \%)$. Under all conditions, but the dark trails at 4 and $10{ }^{\circ} \mathrm{C}$, the decrease was significantly stronger than of $T$. weissflogii.

The chl- $a$ content of Rhodomonas sp. decreased between 17 and $50 \%$ from an initial value of $11.9 \pm 0.6 \mathrm{ng}$ chl- $a$ cell volume ${ }^{-1}$ during all trials. The lowest measured value was observed at $4{ }^{\circ} \mathrm{C} 3$-h light (48.55 \pm 7.44 ; Fig. $3 b)$. Temperature had a negative effect on the chl- $a$ content of Rhodomonas sp.. The chl-a content was lower at lower temperatures as observed during darkness and the $3 \mathrm{~h}$ light treatment. The chl- $a$ content of $T$. weissflogii in contrast only decreased during the dark treatment at $10{ }^{\circ} \mathrm{C} \quad(11.7 \pm 15$. \% from a start value of $5.8 \pm 0.7 \mathrm{ng}$ chl- $a$ cell volume $\left.{ }^{-1}\right)$. Under dark 
Fig. 2 Growth rate day ${ }^{-1}$ at the different pre- and reillumination condition of $T$. weissflogii (white) and Rhodomonas sp. (black bars). Mean value plus standard deviation $(n=3)$. Statistically significantly differences $(p \leq 0.05)$ between the two species are marked with an asterisk

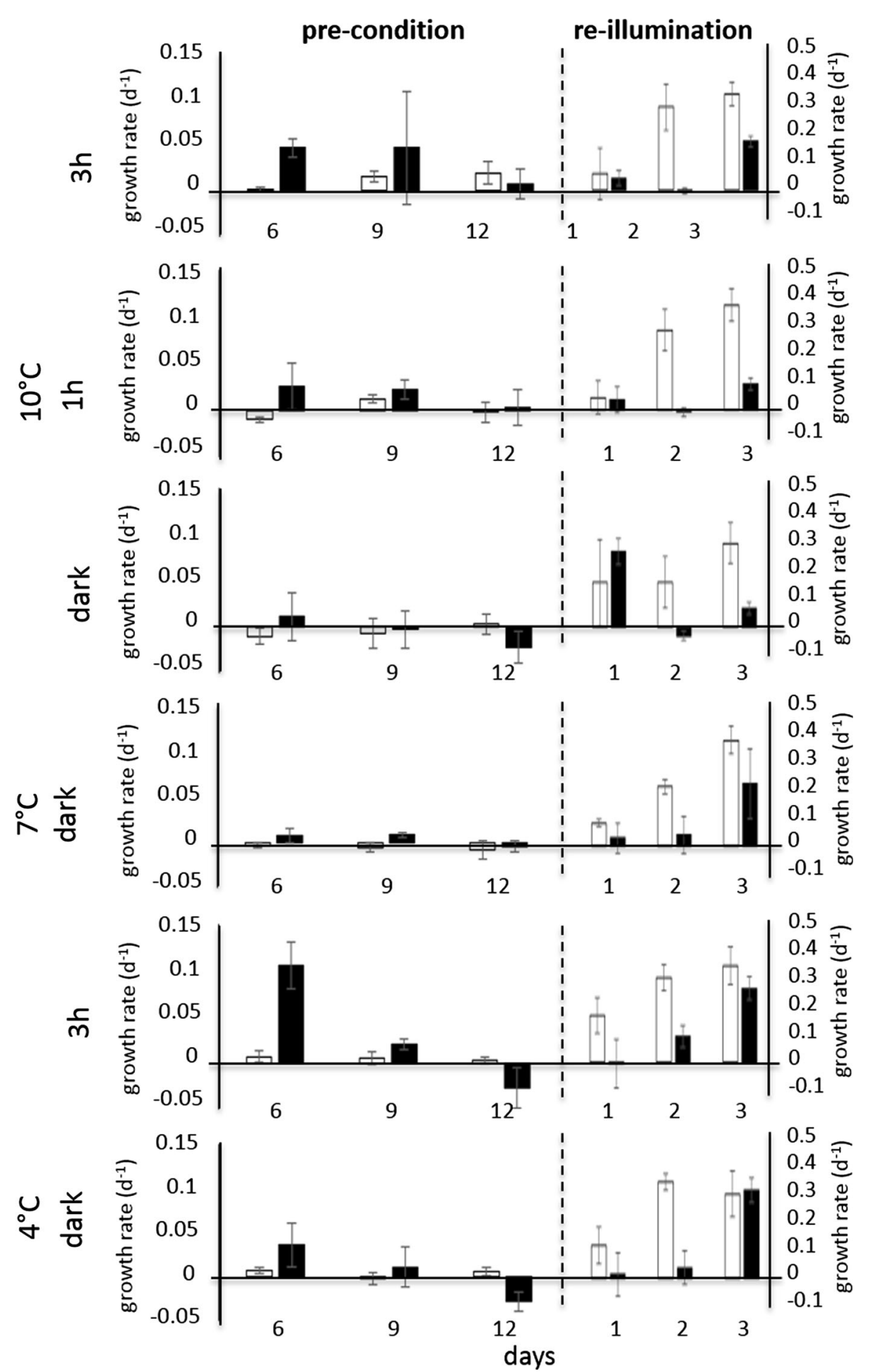

pre-condition re-illumination conditions, the temperature effect on chl- $a$ of $T$. weissflogii was opposite to the effect on Rhodomonas sp. and after 12 days, the content was significantly higher at $4{ }^{\circ} \mathrm{C}$ than at 7 and $10{ }^{\circ} \mathrm{C}(p=0.050)$. A significant increase in chl- $a$ was observed at the $10{ }^{\circ} \mathrm{C}$ $3 \mathrm{~h}$ trial. At all tested conditions, with the exception of 


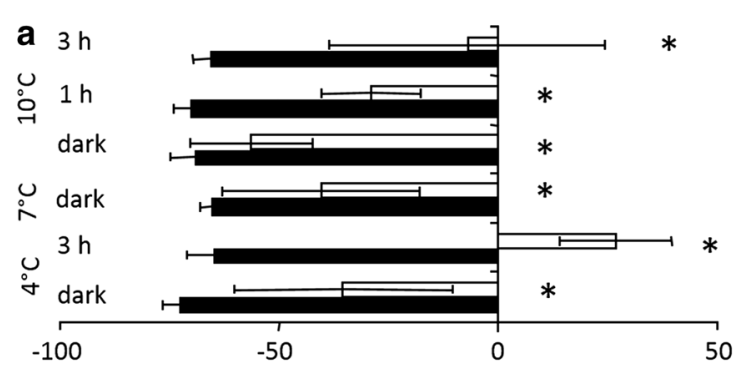

$\%$ differences of carbohydrate content from initial value

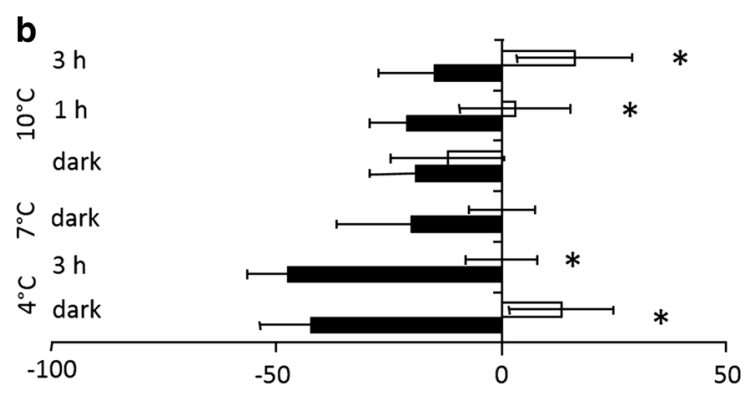

$\%$ differences of chl- $a$ content from initial value

Fig. 3 a Carbohydrate and $\mathbf{b}$ chlorophyll $a$ content as per cent differences from the initial value of $T$. weissflogii (white) and Rhodomonas sp. (black bars). Statistically significantly difference $(p \leq 0.05)$ between the two species are marked with an asterisk

the 7 and $10{ }^{\circ} \mathrm{C}$ dark trial, chl- $a$ in Rhodomonas sp. decreased more than it did in T. weissflogii.

\section{Chlorophyll a fluorescence}

The maximum quantum yield $\left(F_{\mathrm{v}} / F_{\mathrm{m}}\right)$ of both phytoplankton strains was only slightly affected by darkness or low-light conditions (Fig. 4a). The values were $\pm 10 \%$ of the initial value of $0.68 \pm 0.004$ and $0.72 \pm 0.006$ for $T$. weissflogii and Rhodomonas sp., respectively. Only the combination of light and low temperature had a negative effect on the maximum quantum yield. The lowest $F_{\mathrm{v}} / F_{\mathrm{m}}$ values were measured after the exposure to $3 \mathrm{~h}$ light at $4{ }^{\circ} \mathrm{C}$ $(0.63 \pm 0.01$ for $T$. weissflogii and $0.65 \pm 0.03$ for Rhodomonas sp.).

Maximum relative electron transport rate $\left(\mathrm{rETR}_{\max }\right)$ was stronger affected by the different preconditions than $F_{\mathrm{v}} / F_{\mathrm{m}}$. For $T$. weissflogii, all rates decreased during the experiment, with the lowest value of $36.8 \pm 4.7$ at $4{ }^{\circ} \mathrm{C}$ dark, equivalent to a $68 \pm 3.8 \%$ decrease from the initial value (Fig. $4 \mathrm{~b}$ ). The lowest $\mathrm{rETR}_{\max }$ value of Rhodomonas sp. was
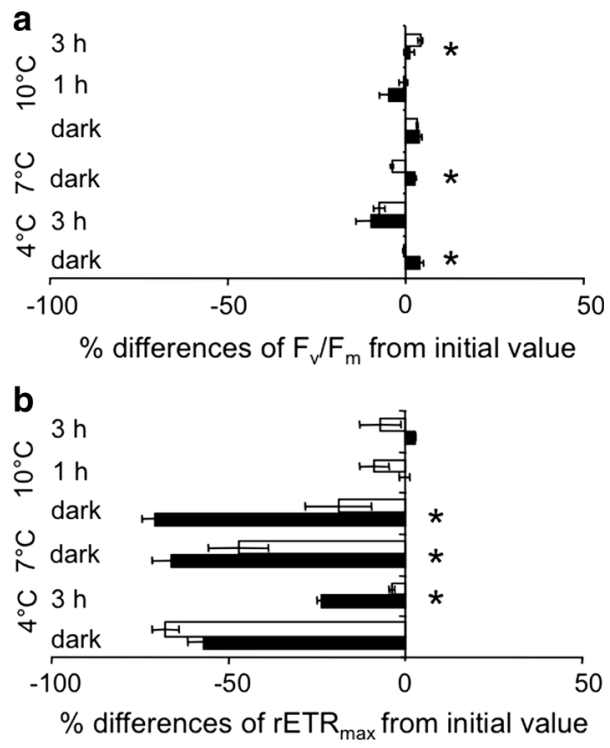

Fig. 4 PAM measurements after 12 days of different winter conditions (a) maximal quantum yield $\left(F_{\mathrm{v}} / F_{\mathrm{m}}\right)$ and (b) maximal electron transport rate $\left(\mathrm{rETR}_{\max }\right)$ as percent differences from the initial value of $T$. weissflogii (white) and Rhodomonas sp. (black bars). Mean values plus standard deviation $(n=3)$. Statistically significantly differences $(p \leq 0.05)$ between the two species are marked with an asterisk

found at $10{ }^{\circ} \mathrm{C}$ dark $(-71 \pm 3.5 \%$ of the initial value of $141 \pm 4)$. Temperature had a significant negative effect on $\mathrm{rETR}_{\max }$ of Rhodomonas sp., whereas it has a positive effect for $T$. weissflogii. Both species could recover their $\mathrm{rETR}_{\max }$ during the $3 \mathrm{~h}$ light period to $75-100 \%$ of the initial value. Cold temperature suppressed the recovery of Rhodomonas sp.. At low light and $4{ }^{\circ} \mathrm{C}$, the $\mathrm{rETR}_{\max }$ of Rhodomonas sp. was significantly lower than at $10{ }^{\circ} \mathrm{C}(p=0.050)$.

Growth after re-illumination

After 12 days of incubation, the two algae strains from all preconditions were re-illuminated with $120 \mu \mathrm{mol}$ photons $\mathrm{m}^{-2} \mathrm{~s}^{-1}$ (Fig. 2). During the second day, growth rate of $T$. weissflogii was significantly higher than growth rate of Rhodomonas sp. for all precondition. After 3 days of re-illumination, this trend could only be observed for algae coming from $10{ }^{\circ} \mathrm{C}$ preconditions. At this day, preconditions had no effect on growth of $T$. weissflogii. The growth rate of Rhodomonas sp. coming from $4{ }^{\circ} \mathrm{C}$ darkness was significantly higher than from $10{ }^{\circ} \mathrm{C}(p=0.050)$. At $10{ }^{\circ} \mathrm{C}$, preconditioning with light had a positive effect 
on growth after re-illumination of Rhodomonas sp. too.

When adding up the growth rates over the tested 3 days, growth rates of $T$. weissflogii during the 3 days of the experiment were significantly higher than of Rhodomonas sp. for algae coming from all preconditions, except from the $10{ }^{\circ} \mathrm{C}$ dark treatment. Temperature during dark precondition had a significant effect on growth of $T$. weissflogii after re-illumination. Growth rates were higher when coming from $4{ }^{\circ} \mathrm{C}$ than 7 and $10{ }^{\circ} \mathrm{C}$ incubation ( $p=0.050$ for both) and correlated with the carbohydrate content after precondition $(p=0.046)$.

\section{Discussion}

Temperate oceanic phytoplankton experiences an annually recurring sequence of low-light, nutrientreplete conditions (winter-spring) and light-sufficient, nutrient-depleted conditions (summer). Margalef (1978) linked these conditions to different life forms with diatoms being generally better adapted to high turbulence, nutrient-replete conditions and flagellates to low turbulence, nutrient-depleted conditions. Jochem (1999) investigated survival of several algae in darkness and noted two strategies: type $I$ cells suppressed their metabolism, while type II cells remained active during darkness. Our experiments were setup to investigate into more detail the response of two different algae strains representing two taxonomic groups (a diatom: T. weissflogii and a flagellate: Rhodomonas sp.) to the combined effect of temperature and very low light availability or constant darkness on the survival and the growth potential after re-illumination.

Based on these results, we will discuss several aspects showing that the diatom $T$. weissflogii was better adapted to survive periods of short light pulses or constant darkness than the flagellate Rhodomonas sp. and reacted faster to improving environmental conditions as simulated by re-illumination. T. weissflogii would out-compete Rhodomonas sp. under natural late winter/spring conditions.
Cell loss and gain during darkness and short light pulses

No appreciable cell loss occurred during 12 days of darkness. This is in line with earlier studies: maximum dark survival times of different phytoplankton species were determined to be between 7 days and several months with species-specific differences in mortality (Antia 1976; Peters 1996; Jochem 1999). Within the range of $4-10^{\circ} \mathrm{C}$, temperature had no significant effect on the dark survival of both species, whereas the lowest average growth rate of both species was found at the $10{ }^{\circ} \mathrm{C}$ dark treatment. However, by testing a larger temperature range of $2-20{ }^{\circ} \mathrm{C}$, Antia (1976) found a strong negative effect of temperature on the maximum dark survival time. Both experimental time and the spread of tested temperatures were not sufficient to demonstrate a significant effect on the metabolism of the tested species.

We found a minor positive effect of short light intervals on the survival of both algae strains. Only few studies were carried out investigating growth under short light pulses ( $\leq 3 \mathrm{~h}$ ) (Walter et al. 2014; Nicklisch et al. 2008). Walter et al. (2014) showed that at temperatures above $8{ }^{\circ} \mathrm{C} \mathrm{T}$. weissflogii exhibited growth rates up to $0.1 \pm 0.02 \mathrm{~d}^{-1}$ at a daily light dose of 0.864 mol photons $\mathrm{m}^{-2} \mathrm{~d}^{-1}$ applied as $2 \mathrm{~h}$ light of an intensity of $120 \mu \mathrm{mol}$ photons $\mathrm{m}^{-2} \mathrm{~s}^{-1}$. In the present study, the daily light dose was only $0.216 \mathrm{~mol}$ photons $\mathrm{m}^{-2} \mathrm{~d}^{-1}$. But even this light dose enabled growth at $10{ }^{\circ} \mathrm{C}$. Our results fall within the range of compensation irradiances of 0.016 and $2.4 \mathrm{~mol}$ photons $\mathrm{m}^{-2} \mathrm{~d}^{-1}$ of different diatom species found by Eilertsen and Degerlund (2010). However, these experiments were carried out under longer light periods with algae coming from a polar region. Shorter light duration may suppress the productivity (Walter et al. 2014).

Effect of constant darkness and short light pulses on physiological conditions of the algae

Both species could withstand 2 weeks of experimental conditions without appreciable cell loss or physiological damage. However, clear differences in the physiological status were observed regarding the photosynthetic performance and content of carbohydrates and chl- $a$. The diatom $T$. weissflogii followed a type $I$ cell: it quickly responded to constant darkness 
by suppressing metabolic activity but maintain photosynthetic capacity. Chl- $a$ changed little in T. weissflogii and only about $30 \%$ of carbohydrates were used during darkness. Low light levels even enabled $T$. weissflogii to counteract carbohydrate loss to some extent. Rhodomonas sp. in contrast followed a type $I I$ cell: cells initially remained active, thereby rapidly depleting carbohydrate reserves, and partially metabolized chl- $a$ resulted in a tendency to generate negative growth rates.

The applied low-light conditions did not markedly improve growth rates. The diatom $T$. weissflogii only showed slight growth at the highest temperature and $3 \mathrm{~h}$ light. Growth rates of the flagellate Rhodomonas sp. tended to be enhanced by short light conditions, but the increase was only during the first days of the experiment after which growth rates tended to decrease in all cases.

Carbohydrates act as a buffer between photosynthesis and growth (Geider 1992), allowing growth during darkness as well as in the light (Lancelot and Mathot 1985; Granum and Myklestad 1999). T. weissflogii could use the short light windows to accumulate carbohydrates. The content at the end of the preconditioning experiment was comparable $\left(10{ }^{\circ} \mathrm{C}\right)$ or even higher than the start value $\left(4^{\circ} \mathrm{C}\right)$. The latter can be explained by the fact that no cell division occurred at $4{ }^{\circ} \mathrm{C}$, and carbohydrates were stored. At the $10{ }^{\circ} \mathrm{C} 3 \mathrm{~h}$ treatment, in contrast the content was comparable to the initial value. The observed slight growth suggests that during the $3 \mathrm{~h}$ light period carbohydrates were produced, presumably enabling cell division. The strong carbohydrate decrease in Rhodomonas sp. showed that the incoming light was not sufficient to accumulate carbohydrates needed for cell division. Since small flagellates are more adapted to low turbulent conditions and their ability to swim usually prevents them from sinking (zero settling velocity of Rhodomonas sp. was, e.g., observed by Sommer 1984), they possibly respond less flexibly to rapidly changing light conditions and therefore did not develop surviving strategies for prolonged darkness (Margalef 1978). Also during our experiment, Rhodomonas sp. continued to grow during the first days in darkness. The carbohydrate content of Rhodomonas sp. decreased about $70 \%$ of the initial value under all tested conditions. This may be related to the relatively high cell division rates at the beginning of the experiment. A similar behavior was, e.g., observed for Anaulus australia (duPreez and Bate 1992). The carbohydrate decrease was most likely linked to the high growth rates at the beginning of the dark period. It is possible that only the essential carbohydrates for maintaining the cell structure remained (Varum et al. 1986). The low carbohydrate concentrations and possibly changed composition at the end of the experiment may have affected growth after re-illumination. Rhodomonas sp. cells used most of their carbohydrate reserves during both dark and the short light periods. This might be the reason for the low growth rates after re-illumination. The growth rates of $T$. weissflogii after re-illumination were significantly affected by previous carbohydrate concentration especially under dark incubation. Cells from treatments resulting in low carbohydrate contents $\left(7\right.$ and $\left.10^{\circ} \mathrm{C}\right)$ had lower growth rates after reillumination.

Chl- $a$ is an indicator for the physiological state during survival of unfavorable conditions. Photoacclimation of algae also may affect growth potential at increasing light availability. During prolonged darkness, algae often reduce their chl- $a$ content to maintain dark metabolism, mostly when carbohydrates, proteins and lipids are already consumed (Peters and Thomas 1996; Katayama et al. 2011). Chl- $a$ of Rhodomonas sp. was reduced to $50 \%$ of the initial value per $\mu \mathrm{m}^{-3}$ cell volume at $4{ }^{\circ} \mathrm{C}$ and about $25 \%$ under the other trials. Short light windows did not induce an increase in chl- $a$. The low chl- $a$ might have additionally caused the delayed growth of Rhodomonas sp. after re-illumination. In contrast, the reduction in chl- $a$ was low for $T$. weissflogii. The lowest value was found after 12 days in darkness at $10{ }^{\circ} \mathrm{C}$, where we also found the lowest carbohydrate contents and the lowest growth rates after re-illumination. Suboptimal start conditions negatively affect growth when being exposed to favorable growth conditions.

A light treatment of $3 \mathrm{~h}$ of $20 \mu \mathrm{mol}$ photons $\mathrm{m}^{-2}$ $\mathrm{s}^{-1}$ induced chl- $a$ accumulation in $T$. weissflogii at $10{ }^{\circ} \mathrm{C}$ indicating low-light acclimation. Many studies showed an increase in chl- $a$ under lower light intensities (Platt et al. 1984; Hammer et al. 2002). However, the light intervals tested so far were always $\geq 6 \mathrm{~h}$, whereas response time of this acclimation process is assumed to be within hours (MacIntyre et al. 2000). Our experiment showed for the first time that a $3 \mathrm{~h}$ light period gave sufficient time to initiate the acclimation process of chl- $a$ accumulation. Light 
duration seems to be the limiting factor, since light limitation due to shorter light intervals $(2 \mathrm{~h})$ of saturating intensities did not induce chl- $a$ accumulation (Walter et al. 2014).

\section{Chlorophyll a fluorescence}

Chlorophyll $a$ fluorometry is a powerful tool to determine the photosynthetic capacity and the acclimation state of PS II to environmental conditions. The maximum quantum yield and the describing parameters of a RLC help to characterize the fitness of the algae and their potential light acceptance (Maxwell and Johnson 2000; Cullen and Davis 2003; Schreiber 2004; Franklin et al. 2009). The maximum quantum yield $\left(F_{\mathrm{v}} / F_{\mathrm{m}}\right)$ is a species-specific parameter describing the reaction of the photosynthetic performance to different environmental conditions (Suggett et al. 2004; Moore et al. 2006). It was constantly high following each precondition, demonstrating that PS II was not negatively affected by 12 days of low-light conditions. Franklin and Berges (2004) demonstrated that $F_{\mathrm{v}} / F_{\mathrm{m}}$ of a dinoflagellate strongly decreased during 3 days of dark incubation, whereas an ice algae community showed no reduction after 15 days of dark incubation (Wulff et al. 2008). Due to the fact that the overall fitness of Rhodomonas sp. was negatively affected by all experimental conditions, the healthiness of the photosynthetic apparatus was unexpected.

The maximum relative electron transport rate $\left(\mathrm{rETR}_{\max }\right)$ calculated from RLCs can be used as an indicator for the ability of the photosystems to utilize the absorbed light energy, thereby reflecting the acclimation to light conditions (Marshall et al. 2000). $\mathrm{rETR}_{\max }$ of Rhodomonas sp. decreased about $70 \%$ during complete darkness at $10{ }^{\circ} \mathrm{C}$. In contrast to chl- $a$, an increase in temperature had a negative effect on $\mathrm{rETR}_{\max }$. Even if the transport rate is not necessarily related to chl- $a$, a stronger decrease in chl- $a$ due to higher stress may also favor a stronger decrease in rETR $_{\text {max }}$ (Lüder et al. 2002).

Photosynthetic activity of both species was positively affected by short light intervals being sufficient for a complete recovery of $\mathrm{rETR}_{\max }$. This agrees with the findings by Nymark et al. (2013) who tested the reillumination behavior of diatoms after $48 \mathrm{~h}$ darkness and found a higher rETR $_{\max }$ after $0.5 \mathrm{~h}$ of reillumination than before dark incubation. $\mathrm{rETR}_{\max }$ did not further increase during the next 6 or $24 \mathrm{~h}$.
Previous investigations on $T$. weissflogii showed a continuous increase in $\mathrm{rETR}_{\max }$ during the first $5 \mathrm{~h}$ of re-illumination (Walter et al. 2014). A decline in $\mathrm{rETR}_{\max }$ as it was found during all dark treatments indicates the onset of degradation of the photosynthetic apparatus (Reeves et al. 2011), but even after a collapse of $\mathrm{rETR}_{\max }$ a full recovery is possible (Lüder et al. 2002; Reeves et al. 2011). Most chl- $a$ fluorescence measurements under dark conditions were carried out on ice algae (Meiners et al. 2009; Ralph et al. 2005) or macroalgae of polar regions (Lüder et al. 2002). Data for temperate pelagic algae are rare (Murphy and Cowles 1997; Popels and Hutchins 2002; Nymark et al. 2013). Even less is known about the effect of short light intervals on photosynthetic capacity.

In summary, our experiments provide unique data of phytoplankton physiology under conditions as they might occur during deep winter mixing especially during late winter and early spring. We could show that short periods of low light intensity kept the photosynthetic apparatus of T. weissflogii and Rhodomonas sp. active. T. weissflogii could even use the short light windows to refill the carbohydrate pool and grow at $10{ }^{\circ} \mathrm{C}$.

The ability of diatoms to survive prolonged darkness is assumed to be due the reduction in the metabolism (French and Hargraves 1980), the formation of resting spores (Durbin 1978; Doucette and Fryxell 1983) or resting cells (Anderson 1975; Hargraves and French 1983). An interruption of the darkness could have a negative effect on dark survival by interfering with the acclimation processes mentioned above. Short light intervals only have a positive effect on dark survival, if algae can produce needed storage resources during these short intervals (French and Hargraves 1980). Diatoms are known to be well adapted to turbulent waters (Margalef 1978; Lavaud et al. 2007), since they can quickly react to changing light availability (Huisman et al. 2004). Our results showed that the diatom $T$. weissflogii has a high flexibility and ability to survive prolong darkness and can quickly respond to available. These properties make diatoms successful competitors in deep mixing conditions. In contrast, the flagellate Rhodomonas sp. benefited from short light interval only during the first days of the experiment. At day 12, the growth rate was zero or negative. 
Precondition effect on growth after re-illumination

We tested the effects of constant darkness and short light pulses on growth after re-illumination and experimentally simulated spring bloom conditions by offering $14 \mathrm{~h}$ light per day of light intensity of $120 \mu \mathrm{mol}$ photons $\mathrm{m}^{-2} \mathrm{~s}^{-1}$ at $10{ }^{\circ} \mathrm{C}$ and monitored the growth rates during the first 3 days. Growth started with a short lag phase of about 1 day independent of preconditions. On the second day, we found that $T$. weissflogii grew faster than Rhodomonas sp. independent of the precondition. The start conditions of $T$. weissflogii (carbohydrate and chl- $a$ contents) were generally better than those of Rhodomonas sp. and seemed to support growth.

In case of a competition for light and nutrients at the onset of a spring bloom, the species with the highest initial growth rate will most likely out-compete other species (Ryabov 2012). Diatoms are typically the first species to bloom in temperate and cold regions (Barlow et al. 1993; Wassmann et al. 1999; Loebl et al. 2007; Wiltshire et al. 2008) possibly because of their high reaction potential to changing environmental conditions (Margalef 1978). Huisman et al. (1999) showed in his competition experiments that the species with the higher initial growth rate outcompeted slower growing species when light was the limiting factor. Although our experiment was not a real competition experiment and we only used one algae strain as a representative of the algae group our findings supports the hypothesis that diatoms potentially out-compete flagellates due to their higher growth rates.

In comparison with real winter conditions, our experiment was rather short. Our experiments, however, focused on the transition between winter and spring and demonstrate that different winter conditions affect the survival as well as the competitive capacity of algae species for this period. It should, however, be noted that even from the maximal extent of the winter mixing onward light availability can support low but significant growth rates (Behrenfeld 2014).

A further increase in temperature by global change may positively affect phytoplankton survival in two ways: some species could benefit from the available light at higher temperatures, since photosynthesis is more dependent on higher temperatures rather than dark respiration (Walter et al. unpublished data). At higher temperatures, photosynthesis increases with more strength than respiration and net primary production increases. Furthermore, higher temperatures may lead to a decrease in the mixed layer depth and therefore extend the light windows. This could lead to a larger winter stock of phytoplankton cells and earlier spring blooms.

Acknowledgements Support for the first author was provided by the Cluster of Excellence "Integrated Climate System Analysis and Prediction" (CliSAP), University of Hamburg, funded through the German Science Foundation (DFG). We would like to thank Martina Wichman and André Eckhardt for technical support, as well as Michael St. John for his support on the experimental design and contributions to an earlier version of the manuscript.

Open Access This article is distributed under the terms of the Creative Commons Attribution 4.0 International License (http:// creativecommons.org/licenses/by/4.0/), which permits unrestricted use, distribution, and reproduction in any medium, provided you give appropriate credit to the original author(s) and the source, provide a link to the Creative Commons license, and indicate if changes were made.

\section{References}

Anderson OR (1975) The ultrastructure and cytochemistry of resting cell formation in Aemphmphora coffaeformis (Bacillariophyceae). J Phycol 11:272-281

Antia NJ (1976) Effects of temperature on the dark survival of marine macroplanktonic algae. Microb Ecol 3(3):41-54

Backhaus JO, Hegseth EN, Wehde H, Irigoien X, Hatten K, Logemann K (2003) Convection and primary production in winter. Mar Ecol Prog Ser 251:1-14

Barlow RB, Mantoura RFC, Gough MA, Fileman TW (1993) Pigment signatures of the phytoplankton composition in the northeastern Atlantic during the 1990 spring bloom. Deep Sea Res Part II 40(1-2):459-477

Behrenfeld MJ (2014) Climate-mediated dance of the plankton. Nat Clim Change 4:880-887

Colebrook JM (1979) Continuous plankton records: seasonal cycles of phytoplankton and copepods in the North Atlantic Ocean and the North Sea. Mar Biol 51:23-32

Cosgrove J, Borrowitzka M (2006) Applying plus amplitude modulation (PAM) fluorometry to microalgae suspensions: stirring potentially impacts fluorescence. Photosyn Res 88(3):343-350

Cullen JJ, Davis RF (2003) The blank can make a big difference in oceanographic measurements. Limnol Oceanogr Bull 12(2):29-56

Dehning I, Tilzer MM (1989) Survival of Scenedesmus acuminatus (Chlorophyceae) in darkness. J Phycol 25(3):509-515 
Deventer B, Heckman C (1996) Effects of prolonged darkness on the relative pigment content of cultured diatoms and green algae. Aquat Sci 58:241-252

Doucette GJ, Fryxell GA (1983) Thalassiosira antarctic: vegetative and resting stage chemical composition of an icerelated marine diatom. Mar Biol 78:1-6

duPreez DR, Bate GC (1992) Dark survival of the surf diatom Anaulus australis Drebes et Schulz. Bot Mar 35:315-319

Dubois M, Gilles K, Hamilton J, Rebers P, Smith F (1956) Colorimetric method for determination of sugar and related substance. Anal Chem 28:350-356

Durbin E (1978) Aspects of the biology of the resting spores of Thalassiosira nordenskioeldii and Detonula confervacae. Mar Biol 45:31-37

Eilertsen H, Degerlund M (2010) Phytoplankton and light during the northern high-latitude winter. J Plankton Res 32:899-912

Franklin DJ, Berges JA (2004) Mortality in cultures of the dinoflagellate Amphidiunium carterae during culture senescence and darkness. Proc R Soc Lond [Biol] 271:2099-2107

Franklin DJ, Choi C, Hughes C, Malin G, Berges J (2009) Effect of dead phytoplankton cells on the apparent efficiency of photosystem II. Mar Ecol Prog Ser 382:35-40

French FW, Hargraves PE (1980) Physiological characteristics of plankton diatom resting spores. Mar Biol Lett 1:185-195

Furusato E, Asaeda T (2009) A dynamic model of darkness tolerance for phytoplankton: model description. Hydrobiologia 619:67-88

Furusato E, Asaeda T, Manatunge J (2004) Tolerance for prolonged darkness of three phytoplankton species, Microcystis aeruginosa (Cyanophyceae), Scenedesmus quadricauda (Chlorophyceae), and Melosira ambigua (Bacillariophyceae). Hydrobiologia 527(1):153-162

Geider RJ (1992) Respiration: taxation without representation. In: Falkowski PG, Woodhead AD (eds) Primary productivity and biogeochemical cycles in the sea. Plenum Press, New York, pp 333-360

Granum E, Myklestad SM (1999) Mobilization of beta-1,3glucan and biosynthesis of amino acid induced by $\mathrm{NH}_{4}{ }^{+}$ addition to $\mathrm{N}$-limited cells of the marine diatom Skeletonema costatum (Bacillariophyceae). J Phycol 35:772-782

Guillard RRL, Ryther JH (1962) Studies of marine planktonic diatoms I. Cyclotella nana Hustedt and Detonula confervacea Cleve. Can J Microbiol 8:229-239

Hammer A, Schumann R, Schubert H (2002) Light and temperature acclimation of Rhodomonas salina (cryptophyceae): photosynthetic performance. Aquat Microb Ecol 29(3):287-296

Hargraves PE, French F (1983) Diatom resting spores: significance and strategies. In: Fryxell GA (ed) Survival strategies of the algae. Cambridge University Press, Cambridge, pp 49

Harris GP (1978) Photosynthesis, productivity and growth: the physiological ecology of phytoplankton. Ergeb Limnol 10:1-171

Herbert D, Phipps P, Strange RE (1971) Chemical analysis of microbial cells. In: Norris J, Ribbons D (eds) Methods in microbiology. Academic Press, London, pp 209
Huisman J, Weissing FJ (1995) Competition for nutrients and light in a mixed water column: a theoretical analysis. Am Nat 146:536-564

Huisman J, Jonker RR, Zonneveld C, Weissing FJ (1999) Competition for light between phytoplankton species: experimental tests of mechanistic theory. Ecology 80:211222

Huisman J, Sharples J, Stroom JM, Visser PM, Kardinaal WEA, Verspagen MHJ, Sommeijer B (2004) Changes in turbulent mixing shift competition for light between phytoplankton species. Ecology 85(11):2960-2970

Jeffrey S, Humphrey G (1975) New spectrophotometric equation for determining chlorophylls $\mathrm{a}, \mathrm{b}, \mathrm{c}_{1}$ and $\mathrm{c}_{2}$ in higher plants, algae and natural phytoplankton. Biochem Physiol Pflanzen Bd 167:191-194

Jochem FJ (1999) Dark survival strategies in marine phytoplankton assessed by cytometric measurement of metabolic activity with fluorescein diacetate. Mar Biol 135(4):721-728

Kashino Y, Kudoh S, Hayashi Y, Suzuki Y, Odate T, Hirawake T, Satoh K, Fukuchi M (2002) Strategies of phytoplankton to perform effective photosynthesis in the North Water. Deep Sea Res Part II 49:5049-5061

Katayama T, Murata A, Taguchi S (2011) Response of pigment composition of the marine diatom Thalassiosira weissfogii to silicate availability during dark survival and recovery. Plankton Benth Res 6(1):1-11

Lancelot C, Mathot S (1985) Biochemical fraction of primary production by phytoplankton in Belgian coastal water during short- and long-term incubation with ${ }^{14} \mathrm{C}$-Bicarbonate. Mar Biol 86:219-226

Lavaud J, Strzepek RF, Kroth PG (2007) Photoprotection capacity differs among diatoms: possible consequences on the spatial distribution of diatoms related to fluctuations in the underwater light climate. Limnol Oceanogr 52(3):1188-1194

Loebl M, Dolch T, van Beusekom JEE (2007) Annual dynamics of pelagic primary production and respiration in a shallow coastal basin. J Sea Res 58:269-282

Lüder UH, Wiencke C, Knoetzel J (2002) Acclimation of photosynthesis and pigments during and after six months of darkness in Palmaria decipiens (Rhodophyta): a study to simulate antarctic winter sea ice cover. J Phycol 38:904-913

MacIntyre HL, Kana TM, Geider RJ (2000) The effect of water motion on short-term rates of photosynthesis by marine phytoplankton. Trends Plant Sci 5(1):12-17

Margalef R (1978) Life-forms of phytoplankton as survival alternative in an unstable environment. Oceanol Acta 1(4):493-509

Marshall H, Geider R, Flynn K (2000) A mechanistic model of photoinhibition. New Phytol 145:347-359

Maxwell K, Johnson GN (2000) Chlorophyll fluorescence-a practical guide. J Exp Bot 51(345):659-668

McMinn A, Martin A (2013) Dark survival in warming world. Proc R Soc B 280:20122909. doi:10.1098/rspb.2012.2909

McQuatters-Gollop A, Raitsos DE, Edwards M, Attrill MJ (2007) Spatial patterns of diatom and dinoflagellate seasonal cycles in the North-East Atlantic Ocean. Mar Ecol Prog Ser 339:301-306 
McQuoid M, Hobson L (1996) Diatom resting stages. J Phycol 32:889-902

McVej JP (1993) CRC handbook of mariculture. Crustacean aquaculture, vol 1, 2nd edn. CRC Press, Boca Raton

Meiners K, Papadimitriou S, Thomas D, Norman L, Dieckmann G (2009) Biogeochemical conditions and ice algal photosynthetic parameters in Weddell Sea ice during early spring. Polar Biol 32(7):1055-1065

Moore CM, Suggett DJ, Hickman AE, Kim YN, Tweddle JF, Sharples J, Geider RG, Holligan PM (2006) Phytoplankton photoacclimation and photoadaptation in response to environmental gradients in a shelf sea. Limnol Oceanogr 51(2):936-949

Murphy AM, Cowles TJ (1997) Effects of darkness on multiexcitation in vivo fluorescence and survival in a marine diatom. Limnol Oceanogr 42(6):1444-1453

Nicklisch A, Shatwell T, Köhler J (2008) Analysis and modelling of the interactive effects of temperature and light on phytoplankton growth and relevance for the spring bloom. J Plankton Res 30(1):75-91

Nymark M, Valle KC, Hancke K, Winge K, Andersen P, Johnsen G, Bones AM, Brembu T (2013) Molecular and photosynthetic responses to prolonged darkness and subsequent acclimation to re-illumination in the diatom Phaeodactylum tricornutum. PLoS ONE 8(3):1-19

Olenina I, Hajdu S, Edler A, Andersson L, Wasmund N, Busch S, Göbel J, Gromisz S, Huseby S, Huttunen M, Jaanus A, Kokkonen P, Ledaine I, Niemkiewicz E (2006) Biovolumes and size-classes of phytoplankton in the Baltic Sea. HELCOM Baltic Sea Environment Proceedings 106

Peters E (1996) Prolonged darkness and diatom mortality: II. Marine temperate species. J Exp Mar Biol Ecol 207:43-58

Peters E, Thomas DN (1996) Prolonged darkness and diatom mortality: I. Marine antarctic species. J Exp Mar Biol Ecol 207:25-41

Platt T, Lewis M, Geider RJ (1984) Thermodynamics of the pelagic ecosystem: elementary closure conditions for biological production in the open ocean. In: Fasham MJR (ed) Flows of energy and materials in marine ecosystems. Plenum Press, New York, pp 49

Popels L, Hutchins DA (2002) Factors affecting dark survival of the brown tide alga Aureococcus anophagefferens (Pelagophyceae). J Phycol 38:738-744

Popels L, MacIntyre HL, Warner ME, Zhang Y, Hutchins DA (2007) Physiological responses during dark survival and recovery in Aureococcus anophagefferens (Pelagophyceae). J Phycol 43:32-42

Ralph PJ, McMinn A, Ryan KG, Ashworth C (2005) Short-term effect of temperature on the photosynthetic of microalgae from the surface layer of Antarctic pack ice. J Phycol 41:763-769

Raven J, Geider R (1988) Temperature and algae growth. New Phytol 110:441-461

Reeves S, McMinn A, Martin A (2011) The effect of prolonged darkness on the growth, recovery and survival of Antarctic Sea ice diatoms. Polar Biol 34(7):1019-1032
Ryabov AB (2012) Phytoplankton competition in deep biomass maximum. Theor Ecol 5:373-385

Schreiber U (2004) Pulse-Amplitude (PAM) fluorometry and saturation pulse method. In: Papageorgiou G (ed) Chlorophyll fluorescence: a signature of photosynthesis. Kluwer Academic Publishers, Dordrecht, pp 279

Smetacek VS (1985) Role of sinking in diatom life-history cycle: ecological, evolutionary and geological significance. Mar Biol 84:239-251

Sommer U (1984) Sedimentation of principal phytoplankton species in Lake Constant. J Plankton Res 6(1):1-14

Stottrup JG, Jensen J (1990) Influence of algal diet on feeding and egg-production of the calanoid copepode Acatia tonsa Dana. J Exp Mar Biol Ecol 141:87-105

Suggett DJ, MacIntyre HL, Geider RJ (2004) Evaluation of biophysical and optical determinations of light absorption by Photosystem II in phytoplankton. Limnol Oceanogr Methods 2:316-332

Talmy D, Blackford J, Hardman-Mountford N, Polimene L, Follows M, Geider R (2014) Flexible C: N ratio enhances metabolism of large phytoplankton when resource supply is intermittent. Biogeosciences 11:5179-5214

Tilman D (1980) Resources: a graphic-mechanistic approach to competition and predation. Am Nat 116:362-393

Varum K, Ostgaard K, Grimsrud K (1986) Diurnal rhythms in carbohydrate metabolism of the marine diatom Skeletonema costatum (Grev.) Cleve. J Exp Mar Biol Ecol 102:249-256

Wagner H, Jakob T, Wilhelm C (2006) Balancing the energy flow from captured light to biomass under fluctuating light conditions. New Phytol 169(1):95-108

Walter B, Peters J, van Beusekom JEE, St John MA (2014) Interactive effects of temperature and light during deep convection: a case study on growth and condition of the diatom Thalassiosira weissflogii. ICES J Mar Sci. doi:10. 1093/icesjms/fsu 218

Wasmund N (1989) Micro-autoradiographic determination of the viability of algae inhabiting deep sediment layers. Estuar Coast Shelf Sci 28:651-656

Wassmann P, Ratkova T, Andreassen I, Vernet M, Pedersen G, Rey F (1999) Spring bloom development in the marginal ice zone and the central Barents Sea. Mar Ecol 20(3-4):321-346

White A (1974) Growth of two facultatively heterotrophic marine centric diatoms. J Phycol 10:292-300

Wiltshire KH, Malzahn A, Greve W, Wirtz K, Janisch S, Mangelsdorf P, Manly BF, Boersma M (2008) Resilience of North Sea phytoplankton spring blooms dynamics: an analysis of long term data at Helgoland Roads. Limnol Oceanogr 53:1294-1302

Wulff A, Roleda MY, Zacher K, Wienk C (2008) Exposure to sudden light burst after prolonged darkness-a case study on benthic diatoms in Antarctica. Diatom Res 23(2):519-553 